\title{
Foreign Currency Hedging Case Study: Jacques Couture, Inc.
}

\author{
Prof. Ronald Richter', Prof. Arthur S. Guarino², \& Joshua Schupak ${ }^{3}$ \\ ${ }^{1}$ MBA, Department of Finance and Economics, Rutgers University, New Jersey, US. \\ ${ }^{2}$ MBA, MSSc, JD, Department of Finance and Economics, Rutgers University, New Jersey, US. \\ ${ }^{3}$ Undergraduate Finance Student, Department of Finance and Economics, Rutgers University, \\ New Jersey, US \\ DOI - http://doi.org/10.37502/IJSMR.2021.4804
}

\begin{abstract}
This case study deals with a clothing manufacturing firm that must deal with foreign currency exchange and hedging. The firm's chief financial officer must evaluate the foreign exchange transaction exposure since the company sells its products in foreign markets and has foreign currency exposure that affects earnings. The firm must set its prices to customers before the product is sent to its retail customers overseas. The firm must contend with a long lead time, one year to 18 months, before the retail customer commits to purchasing the merchandise. The firm not only contends with foreign currency exchange risk when selling its products overseas, but must also purchase fabric and other materials in currencies other than U.S. dollars. The firm sells its products globally and, therefore, is very often using different currencies with various retail customers and suppliers. The firm seeks to limit its exposure to foreign currency transaction risk, while lowering its variability of costs and sustaining its profitability. The chief financial officer must make an accurate forecast for the next twelve months of the foreign exchange transaction exposure and determine how to hedge that risk. The chief financial officer also has the task of not allowing net profits to decrease due to currency movements even if revenues are increasing.
\end{abstract}

Keywords: Active hedging, FASB 52, Hedging, Natural hedging.

\section{Introduction}

Emma Wang is the Chief Financial Officer (CFO) for Jacques Couture, Incorporated located in New York City. The company is a large firm manufacturing clothing for the younger market and sells its products globally. The company makes its own line of clothing ranging from sportswear for young adults to a casual line for young teenagers just starting high school. The industry is demanding since the company must change its clothing line at least twice, sometimes three times a year, due to the changing styles and tastes by its young cliental. This keeps the design team constantly on its toes due to changing styles young people and teenager's desire. The designers and the research staff are always trying to find out what young people like and do not like ranging 
from colors, cut of the material to the type of fabric used. While the company has been growing and has kept pace with changes in styles and tastes, the rate of growth has not been steady and the competition has been ruthless. The company has faced problems with manufacturing, transportation, the ever-changing styles and tastes of teenagers, and even keeping abreast of foreign policy when it comes to trade and tariffs and how they will affect business. A huge problem the company faces is purchasing fabric and other materials in currencies other than the currencies of each subsidiary. As CFO, Emma has been aware of the problems that changing value of currency can bring and how it will affect not only costs but also revenues and operating and net profits for the company. With global customers, the company uses diverse currencies when selling product to different retail customers. But dealing with different currencies means being exposed to a greater amount of risk, especially when the level of tolerance can be relatively low given the state of the world's macroeconomy and the cutthroat competition in the clothing manufacturing industry. Emma has had to become an expert in hedging foreign currency so that it will not hurt the revenues, operating profits and net profits of the firm while also attempting to forecast what will occur in the next twelve months regarding exposure to transaction risk. Dealing with currency volatility has kept Emma awake too many nights so that the company's profits do not take a severe loss.

\section{Company Background}

Jacques Couture, Incorporated started in the bedroom of a small apartment in the Bronx by two roommates who worked in the fashion industry in New York City. Jill Abramowitz and Maria Gambino had attended the Fashion Institute in Manhattan and graduated together with dreams of becoming designers for a famous fashion house, either in New York City, Paris or Milan. Jill worked for a manufacturer who would make knockoffs from coats she was told to purchase at Bergdorf Goodman or Neiman Marcus. She liked the challenge of copying someone else's work, and the pay was decent, but it still did not feel right. The only redeeming aspect to her job was that sometimes she would add her personal touch to the patterns and her boss never caught on.

Maria worked for Macy's when she completed her degree at the Fashion Institute and started as a buyer. While the job paid the bills, she wanted to design casual wear and would bring her portfolio of designs and ideas to different manufacturers and fashion houses in New York City. Jill and Maria graduated college in 1973, and lived together in a small apartment on Arthur Avenue in the Bronx. Both were frustrated with their careers, and after much thought and what seemed like endless conversations, they decided to strike out on their own and start a company.

At first, they were not sure which line of fashion they would pursue, but after talking about different possibilities, speaking with numerous people, and from what they knew about the clothing industry, they decided to start with sportswear for young adults. The clothing line would be geared toward young people, male and female, in the age category of 18 to 25 years old. Jill and Maria wanted to make their brand not only for casual wear but also for the urban setting. They felt that if their line was getting the attention of young people in New York City, then word would 
eventually spread to the suburbs. They knew which market they wanted to penetrate and how to design, price, and market their clothing line.

Jill and Maria worked nights and weekends designing, making sample clothing, and talking to young people about what they liked and did not like. They met with young people in the New York City metropolitan area, from Harlem to Long Island. Each of them always had a pad and pencil which they used for either making designs, sketches, or jotting down what information they received from talking to anyone and everyone. After talking with a young lawyer, their dreams turned into a collective panic attack. The problem was that while both had become more knowledgeable about fashion, design, and their target market than they ever learned in college, they knew nothing about starting a business.

They had to become familiar at an extremely fast rate with such concepts as an income statement, cash flow, and taxes, whether to incorporate or form a partnership, financing, and constructing a balance sheet. Deep down inside they knew they would need money and lots of it to start their business venture, but they did not know the difference between a commercial loan and forming a partnership with a venture capitalist. The young lawyer they spoke with at a holiday party in Manhattan was able to give them the name of a business consultant who had an office in the city. The consultant was an older woman, Sally DuPont, who had a solo practice and did a variety of financial work from helping startups get off the ground to advising companies looking at bankruptcy proceedings. The consultant took a liking to Jill and Maria and after hearing what they wanted to do but not having the technical knowledge needed to start a business, she agreed to advise them on an ongoing basis for a small percentage of ownership of their venture. Sally knew of a clothing manufacturer, Irv Levi, who was in business for many years and was thinking of retiring eventually. Sally felt the manufacturer could sell 80 percent of his business to Jill and Maria and show them how to run a shop. When Jill and Maria were ready in a few years to take over the shop completely, he would sell the rest to them. Sally would get 2 percent of Jill and Maria's part.

With the help of Sally, they were able to negotiate a price with Irv. Jill and Maria used their personal savings, some inheritance money from Jill's grandparents, and other funds that they were able to borrow from friends and family. Jill and Maria worked hard at growing the business and after a few tight years, were able to start seeing a significant profit in their fifth year. They found they were able to sell their clothing line not only in the United States, but also globally. What really helped was that their clothing was featured in a movie shot in Manhattan and the film's star helped promote the line wherever she travelled.

Jill and Maria were able to buy the business from Irv and even move to a bigger shop location in Manhattan because their company grew larger every year. But this also meant hiring more people who dealt with designing, marketing, administration, finance, and accounting. While things sometimes got hairy, the business was growing and Jill and Maria were even approached by Wall Street investment bankers about taking the company public by selling common shares on 
NASDAQ. "Who would have thought?" Maria said to herself as the investment banker made her pitch in a board room overlooking lower Manhattan.

\section{Current Situation}

Emma Wang has been with Jacques Couture, Incorporated for the past ten years and handled various aspects of the company's financial obligations. She realized that the company had to deal with the daily changes in accounts receivables and accounts payables due to fluctuations in currency values. Complicating matters was that she needed to forecast accounts receivables and accounts payables in U.S. dollar equivalents. The company had grown substantially with subsidiaries in Canada, various parts of Europe, Great Britain, and Japan.

Due to the various subsidiaries Emma had become familiar with the role of hedging diverse currencies in order to minimize any possible financial losses the company could encounter. For active hedging she used forward contracts, put and call options and natural hedging when appropriate. Active hedging is the minimization of market timing risk while reducing negative cash flows for when the base currency weakens. The objective of active hedging is to protect a portfolio from any losses related to exposure to foreign currency. In natural hedging, management was determining the overall net currency exposure in various currencies to off-set long and short positions prior to purchasing active hedging products (forwards and options).. A subsidiary generating revenue in another country's currency can offset its risk with exposure from other subsidiaries in identifying the natural hedges.

However, Emma needed to find the cheapest hedge in order to ensure against risk in the least expensive way possible. The overall objective was to hedge 80 to 100 percent of currency risk. But this meant quantifying risk and how it would affect the company. Emma needed to hedge the currency risk exposure the company would face by using a combination of forward contracts and/or options. Like most other aspects of her job as CFO, she needed to forecast what would occur with the different currencies her company dealt with and that it needed to be accurate.

One guideline Emma used was FASB Rule 52. This rule is a guideline for accounting for foreign currency risk that was issued by the Financial Accounting Standards Board (FASB). FASB 52 identifies the difference between transaction and translation exposure, and Emma is concerned only about transaction exposure as cash flows are affected to these types of currency exposures. Transaction exposure occurs in a company's accounts receivables and payables and results in either an increase or decrease in cash flows depending on currency movements.

Emma needed help in this matter, and she decided to enlist her assistant, Rosario Pagana, whom she recently hired out of graduate school. Emma needed to write a detailed memorandum outlining the situation and seeking his input on how she should proceed. Emma would pass on the key financial information to Rosario so he could make an accurate assessment as to what should be done. 
Emma wrote a memo to Rosario addressing the foreign currency transaction risk.

\section{Assignment Memo:}

To: Rosario Pagana (Student) - Financial Analyst

From: Emma Wang - Chief Financial Officer

Date: January 31, 2021

$\boldsymbol{R e}$ : Foreign Currency Transaction Exposure Analysis

We are getting concerned about the foreign currency transaction exposures effect on our cash flow and profits. We need to come up with a hedging strategy the mitigate the risk of currency movement on our business. We have forecasted the Accounts Receivables and Accounts Payables for the next 12 months and we also received quoted exchange rates for the spot market and forward markets along with option premium quotes.

Please put together a hedging strategy for Jacques Couture, Inc. to address the following issues:

1. What are the calculated net currency transaction exposures for the company after taking into account natural hedges within Jacques Couture?

2. When devising your hedging strategy, indicate why you chose various financial instruments to hedge the net exposures (Forward contacts, option contracts or a combination of the two). Remember, we are looking to hedge 80-100 percent of the transaction exposure risk.

3. Indicate any other items we need to think about as we are putting together a hedging strategy. Why are these items important?

Your response to this memo includes your answers to the above with supporting calculations. It is imperative that we fully understand why you chose your strategy and what you think will be the impact on earnings/cashflows with your strategy.

I need your reply with your recommendations in one week. 
53 | International Journal of Scientific and Management Research 4(8) 48-58

The following exhibits illustrates the forecasted currency exposure for the next 12 months:

As these numbers are expressed in US dollars, they are actually receivables in the currency represented. For example, the Canadian

Subsidiary has receivables over the next 12 months in Euros, Great British Pounds, US Dollars and Japanese Yen).

\begin{tabular}{|c|c|c|c|c|c|c|c|c|c|c|c|c|c|c|c|c|c|c|c|c|c|c|c|c|}
\hline \multirow[b]{2}{*}{ Month } & \multicolumn{24}{|c|}{$\begin{array}{l}\text { Jacques Couture, Inc. } \\
\text { Accounts Receivables (expressed in \$000's in US\$ equivalents) }\end{array}$} \\
\hline & \multicolumn{3}{|c|}{1} & \multicolumn{2}{|c|}{2} & \begin{tabular}{l|l|l}
3 & \\
\end{tabular} & & \multicolumn{2}{|c|}{41} & \multicolumn{2}{|c|}{\begin{tabular}{|l|l}
5 \\
\end{tabular}} & \multicolumn{2}{|l|}{6} & \multicolumn{2}{|c|}{7} & \multicolumn{2}{|l|}{8} & \multicolumn{2}{|c|}{9 I } & \multicolumn{2}{|l|}{10} & 11 & \multicolumn{2}{|r|}{12} \\
\hline \multicolumn{25}{|c|}{ Canadian Subsidiary } \\
\hline EUR & $\$$ & 1,140 & $\$$ & 1,080 & $\$$ & 1,110 & $\$$ & 960 & $\$$ & 1,190 & $\$$ & 870 & $\$$ & 1,010 & $\$$ & 890 & $\$$ & 1,190 & $\$$ & 850 & $\$$ & 830 & $\$$ & 1,050 \\
\hline GBP & $\$$ & 970 & $\$$ & 950 & $\$$ & 860 & $\$$ & 1,060 & $\$$ & 1,070 & $\$$ & 800 & $\$$ & 870 & $\$$ & 1,030 & $\$$ & 960 & $\$$ & 810 & $\$$ & 1,180 & $\$$ & 980 \\
\hline USD & $\$$ & 1,090 & $\$$ & 970 & $\$$ & 1,200 & $\$$ & 860 & $\$$ & 880 & $\$$ & 980 & $\$$ & 1,070 & $\$$ & 810 & $\$$ & 1,140 & $\$$ & 1,110 & $\$$ & 1,040 & $\$$ & 1,090 \\
\hline YEN & $\$$ & 1,070 & $\$$ & 800 & $\$$ & 860 & $\$$ & 1,050 & $\$$ & 910 & $\$$ & 940 & $\$$ & 890 & $\$$ & 890 & $\$$ & 930 & $\$$ & 1,040 & $\$$ & 1,150 & $\$$ & 1,120 \\
\hline \multicolumn{25}{|c|}{ European Subsidairy } \\
\hline CAD & $\$$ & 990 & \$s & 840 & $\$$ & 1,060 & $\$$ & 820 & $\$$ & 1,000 & $\$$ & 1,080 & $\$$ & 1,020 & $\$$ & 910 & $\$$ & 880 & $\$$ & 1,130 & $\$$ & 910 & $\$$ & 1,040 \\
\hline GBP & $\$$ & 920 & $\$$ & 1,100 & $\$$ & 1,130 & $\$$ & 1,030 & $\$$ & 1,030 & $\$$ & 1,010 & $\$$ & 1,030 & $\$$ & 1,180 & $\$$ & 1,070 & $\$$ & 1,020 & $\$$ & 1,050 & $\$$ & 920 \\
\hline USD & $\$$ & 900 & $\$$ & 1,090 & $\$$ & 910 & $\$$ & 1,120 & $\$$ & 1,090 & $\$$ & 880 & $\$$ & 1,000 & $\$$ & 930 & $\$$ & 990 & $\$$ & 890 & $\$$ & 850 & $\$$ & 960 \\
\hline YEN & $\$$ & 820 & \$ & 800 & $\$$ & 1,040 & $\$$ & 960 & $\$$ & 1,190 & $\$$ & 880 & $\$$ & 820 & $\$$ & 850 & $\$$ & 860 & $\$$ & 850 & $\$$ & 1,190 & $\$$ & 960 \\
\hline \multicolumn{25}{|c|}{ Japanese Subsidiary } \\
\hline CAD & $\$$ & 990 & \$ & 810 & $\$$ & 1,110 & $\$$ & 1,010 & $\$$ & 850 & $\$$ & 1,040 & $\$$ & 870 & $\$$ & 1,050 & $\$$ & 980 & $\$$ & 1,190 & $\$$ & 970 & $\$$ & 1,120 \\
\hline EUR & $\$$ & 1,030 & $\$$ & 990 & $\$$ & 1,180 & $\$$ & 890 & $\$$ & 1,200 & $\$$ & 850 & $\$$ & 1,010 & $\$$ & 1,140 & $\$$ & 1,050 & $\$$ & 820 & $\$$ & 810 & $\$$ & 1,050 \\
\hline GBP & $\$$ & 1,190 & $\$$ & 1,200 & $\$$ & 810 & $\$$ & 1,130 & $\$$ & 960 & $\$$ & 890 & $\$$ & 880 & $\$$ & 1,100 & $\$$ & 1,160 & $\$$ & 930 & $\$$ & 1,060 & $\$$ & 890 \\
\hline USD & $\$$ & 850 & $\$$ & 1,050 & $\$$ & 1,140 & $\$$ & 810 & $\$$ & 1,000 & $\$$ & 870 & $\$$ & 1,150 & $\$$ & 1,180 & $\$$ & 890 & $\$$ & 870 & $\$$ & 860 & $\$$ & 1,200 \\
\hline \multicolumn{25}{|c|}{ UK Subsidiary } \\
\hline CAD & $\$$ & 1,180 & \$ & 1,200 & $\$$ & 1,050 & $\$$ & 1,180 & $\$$ & 860 & $\$$ & 930 & $\$$ & 1,030 & $\$$ & 1,070 & $\$$ & 890 & $\$$ & 930 & $\$$ & 840 & $\$$ & 1,110 \\
\hline EUR & $\$$ & 1,070 & \$ & 1,060 & $\$$ & 1,120 & $\$$ & 800 & $\$$ & 860 & $\$$ & 900 & $\$$ & 1,120 & $\$$ & 900 & $\$$ & 1,010 & $\$$ & 1,130 & $\$$ & 850 & $\$$ & 1,020 \\
\hline USD & $\$$ & 1,030 & $\$$ & 1,030 & $\$$ & 1,130 & $\$$ & 890 & $\$$ & 1,180 & $\$$ & 920 & $\$$ & 1,100 & $\$$ & 1,070 & $\$$ & 1,200 & $\$$ & 1,080 & $\$$ & 900 & $\$$ & 1,150 \\
\hline YEN & $\$$ & 1,010 & $\$$ & 1,000 & $\$$ & 1,130 & $\$$ & 1,100 & $\$$ & 1,200 & $\$$ & 990 & $\$$ & 1,180 & $\$$ & 1,020 & $\$$ & 1,080 & $\$$ & 890 & $\$$ & 940 & $\$$ & 840 \\
\hline \multicolumn{25}{|c|}{ US Parent } \\
\hline CAD & $\$$ & 990 & $\$$ & 850 & $\$$ & 1,100 & $\$$ & 1,130 & $\$$ & 1,070 & $\$$ & 1,010 & $\$$ & 1,200 & $\$$ & 870 & $\$$ & 1,170 & $\$$ & 1,120 & $\$$ & 820 & $\$$ & 1,180 \\
\hline EUR & $\$$ & 810 & $\$$ & 1,020 & $\$$ & 820 & $\$$ & 1,100 & $\$$ & 1,170 & $\$$ & 970 & $\$$ & 950 & $\$$ & 1,140 & $\$$ & 900 & $\$$ & 830 & $\$$ & 1,120 & $\$$ & 1,150 \\
\hline GBP & $\$$ & 870 & $\$$ & 1,030 & $\$$ & 950 & $\$$ & 830 & $\$$ & 1,050 & $\$$ & 1,160 & $\$$ & 1,090 & $\$$ & 910 & $\$$ & 800 & $\$$ & 920 & $\$$ & 950 & $\$$ & 810 \\
\hline YEN & $\$$ & 930 & $\$$ & 1,150 & $\$$ & 1,110 & $\$$ & 810 & $\$$ & 870 & $\$$ & 830 & $\$$ & 920 & $\$$ & 1,010 & $\$$ & 830 & $\$$ & 1,140 & $\$$ & 1,110 & $\$$ & 930 \\
\hline
\end{tabular}


54 | International Journal of Scientific and Management Research 4(8) 48-58

As these numbers are expressed in US dollars, they are actually payables in the currency represented. For example, the Canadian Subsidiary has payables over the next 12 months in Euros, Great British Pounds, US Dollars and Japanese Yen).

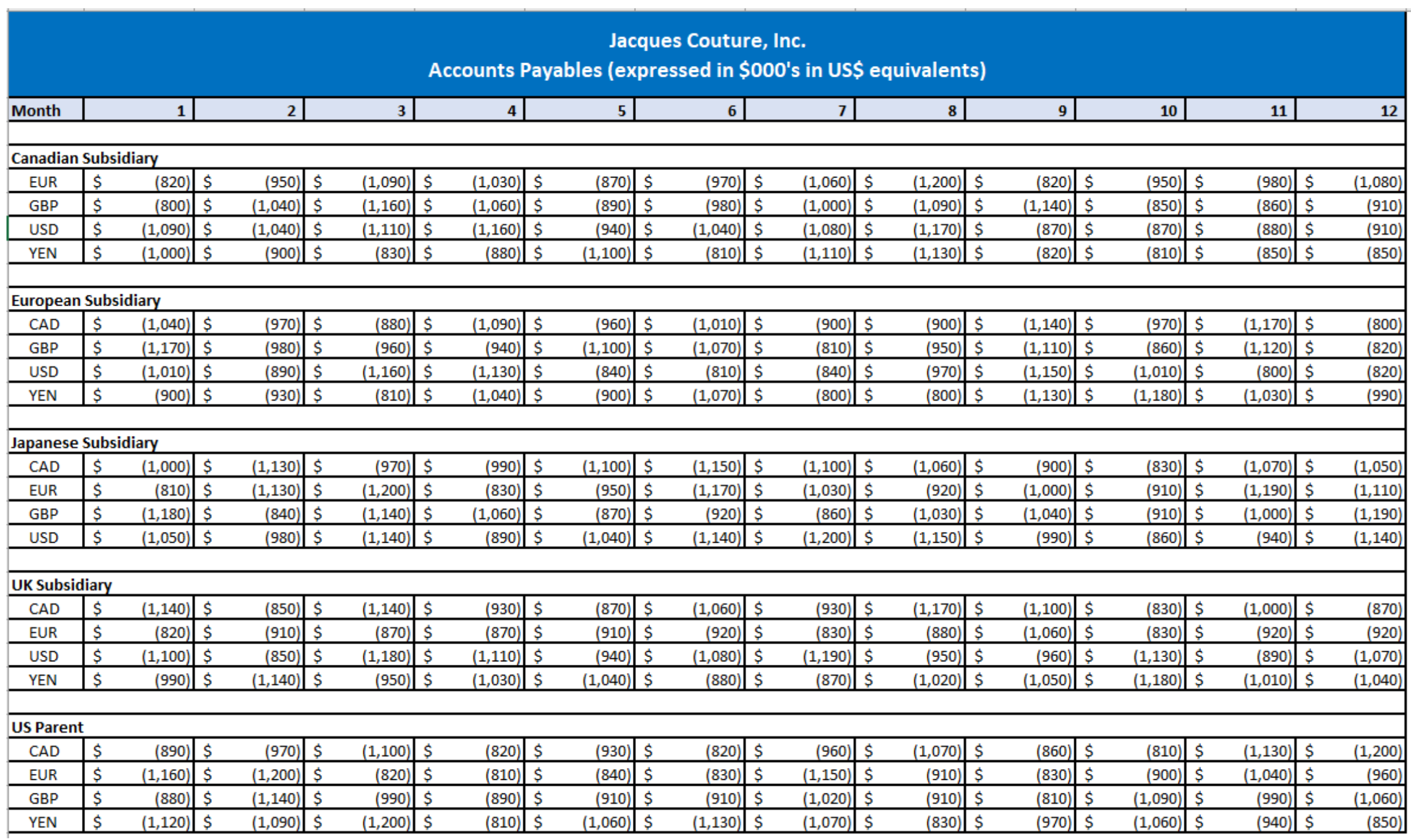


These following illustrations give you information about the currency exchange rates both in the spot market and forward markets, and options premium prices against the US\$.

Currency Rates

\begin{tabular}{|l|r|r|r|r|}
\hline \multicolumn{1}{|c|}{ Expiration } & EUR & GB P & CAD & \multicolumn{1}{c|}{ JPY } \\
\cline { 2 - 5 } Overnight & 0.843028 & 0.766754 & 1.31270 & 104.75998 \\
\hline Tomorrow Next & 0.843099 & 0.766754 & 1.31270 & 104.75998 \\
\hline Spot Next & 0.843099 & 0.766754 & 1.31270 & 104.75999 \\
\hline One Week & 0.842957 & 0.766754 & 1.31270 & 104.75994 \\
\hline Two Weeks & 0.842815 & 0.766754 & 1.31260 & 104.75988 \\
\hline Three Weeks & 0.842744 & 0.766695 & 1.31260 & 104.75983 \\
\hline One Month & 0.842531 & 0.766636 & 1.31260 & 104.75977 \\
\hline Two Months & 0.841963 & 0.766518 & 1.31250 & 104.7594 \\
\hline Three Months & 0.841255 & 0.766284 & 1.31210 & 104.75911 \\
\hline Four Months & 0.840689 & 0.766166 & 1.31200 & 104.75881 \\
\hline Five Months & 0.840124 & 0.766049 & 1.31200 & 104.7584 \\
\hline Six Months & 0.83956 & 0.765931 & 1.31190 & 104.75811 \\
\hline Seven Months & 0.838997 & 0.765814 & 1.31190 & 104.75778 \\
\hline Eight Months & 0.838434 & 0.765697 & 1.31190 & 104.74734 \\
\hline Nine Months & 0.837872 & 0.76558 & 1.31180 & 104.74698 \\
\hline Ten Months & 0.837311 & 0.765462 & 1.31180 & 104.74661 \\
\hline Eleven Months & 0.83668 & 0.765345 & 1.31180 & 104.74569 \\
\hline One Year & 0.83612 & 0.765228 & 1.31180 & 104.74527 \\
\hline
\end{tabular}

Option Premiums Costs verse the US \$ for each month.

\begin{tabular}{|c|c|c|c|c|c|c|c|c|c|c|c|c|}
\hline \multicolumn{13}{|c|}{ PUT OPTIONS } \\
\hline Month & 1 & 2 & 3 & 4 & 5 & 6 & 7 & 8 & 9 & 10 & 11 & 12 \\
\hline EUR & $1.2 \%$ & $1.5 \%$ & $1.7 \%$ & $1.9 \%$ & $2.1 \%$ & $2.2 \%$ & $2.4 \%$ & $2.7 \%$ & $2.9 \%$ & $3.1 \%$ & $3.3 \%$ & $3.5 \%$ \\
\hline GBP & $1.9 \%$ & $2.5 \%$ & $2.9 \%$ & $3.4 \%$ & $3.8 \%$ & $4.3 \%$ & $4.5 \%$ & $4.7 \%$ & $4.9 \%$ & $5.1 \%$ & $5.3 \%$ & $5.5 \%$ \\
\hline CAD & $0.80 \%$ & $1.08 \%$ & $1.12 \%$ & $1.29 \%$ & $1.46 \%$ & $1.63 \%$ & $1.76 \%$ & $1.89 \%$ & $2.02 \%$ & $2.15 \%$ & $2.28 \%$ & $2.41 \%$ \\
\hline JPY & $0.74 \%$ & $1.02 \%$ & $1.02 \%$ & $1.27 \%$ & $1.51 \%$ & $1.76 \%$ & $1.89 \%$ & $2.02 \%$ & $2.14 \%$ & $2.27 \%$ & $2.40 \%$ & $2.53 \%$ \\
\hline
\end{tabular}

\begin{tabular}{|c|c|c|c|c|c|c|c|c|c|c|c|c|}
\hline \multicolumn{13}{|c|}{ CALL OPTIONS } \\
\hline Month & 1 & 2 & 3 & 4 & 5 & 6 & 7 & 8 & 9 & 10 & 11 & 12 \\
\hline EUR & $0.9 \%$ & $1.3 \%$ & $1.6 \%$ & $1.8 \%$ & $2.1 \%$ & $2.3 \%$ & $2.5 \%$ & $2.6 \%$ & $2.7 \%$ & $2.8 \%$ & $2.9 \%$ & $3.1 \%$ \\
\hline GBP & $1.6 \%$ & $2.0 \%$ & $2.4 \%$ & $2.6 \%$ & $2.7 \%$ & $2.9 \%$ & $3.1 \%$ & $3.3 \%$ & $3.5 \%$ & $3.8 \%$ & $4.0 \%$ & $4.2 \%$ \\
\hline CAD & $1.00 \%$ & $1.27 \%$ & $1.73 \%$ & $1.90 \%$ & $2.08 \%$ & $2.25 \%$ & $2.39 \%$ & $2.52 \%$ & $2.66 \%$ & $2.79 \%$ & $2.93 \%$ & $3.06 \%$ \\
\hline JPY & $1.04 \%$ & $1.35 \%$ & $1.35 \%$ & $1.66 \%$ & $1.97 \%$ & $2.28 \%$ & $2.45 \%$ & $2.62 \%$ & $2.80 \%$ & $2.97 \%$ & $3.15 \%$ & $3.32 \%$ \\
\hline
\end{tabular}




\section{Glossary of Terms}

\section{Active Hedging (A Beginner's Guide to Hedging) ${ }^{1}$}

The best way to understand hedging is to think of it as a form of insurance. When people decide to hedge, they are insuring themselves against a negative event's impact on their finances. This doesn't prevent all negative events from happening. However, if a negative event does happen and you're properly hedged, the impact of the event is reduced.

\section{Cash flow Hedge ${ }^{2}$}

A cash flow hedge is a hedge of the exposure to variability in the cash flows of a specific asset or liability, or of a forecasted transaction, that is attributable to a particular risk.

\section{FASB 52 ${ }^{3}$}

Application of this Statement will affect financial reporting of most companies operating in foreign countries. The differing operating and economic characteristics of varied types of foreign operations will be distinguished in accounting for them. Adjustments for currency exchange rate changes are excluded from net income for those fluctuations that do not impact cash flows and are included for those that do.

\section{Forward Contracts ${ }^{4}$}

A currency forward is a binding contract in the foreign exchange market that locks in the exchange rate for the purchase or sale of a currency on a future date. A currency forward is essentially a customizable hedging tool that does not involve an upfront margin payment. The other major benefit of a currency forward is that its terms are not standardized and can be tailored to a particular amount and for any maturity or delivery period, unlike exchange-traded currency futures.

\section{Interest Rate Parity ${ }^{5}$}

Interest rate parity (IRP) plays an essential role in foreign exchange markets connecting interest rates, spot exchange rates, and foreign exchange rates. Interest rate parity (IRP) is a theory according to which the interest rate differential between two countries is equal to the differential between the forward exchange rate and the spot exchange rate.

\section{Natural Hedging6,7}

A natural hedge is a management strategy that seeks to mitigate risk by investing in assets whose performances are inherently negatively correlated. For instance, a natural hedge against

\footnotetext{
${ }^{1}$ https://www.investopedia.com/trading/hedging-beginnersguide/\#: :text=Hedging\%20against\%20investment\%20risk\%20means, making\%20a\%20trade\%20in\%20another

2 https://www.accountingtools.com/articles/2017/5/5/cash-flow-hedge

${ }^{3}$ https://www.fasb.org/summary/stsum52.shtml

${ }^{4}$ https://www.investopedia.com/terms/c/currencyforward.asp

${ }^{5}$ https://www.investopedia.com/terms/i/interestrateparity.asp

${ }^{6}$ https://www.investopedia.com/terms/n/natural-hedge.asp

${ }^{7}$ https://www.cambridgefx.com/blog/foreign-exchange-hedging-for-businesses-your-questions-answered/
} 
owning financial stocks is to hold bonds, since interest rate changes tend to influence each in opposite fashion,

A natural hedge can also be implemented when institutions exploit their normal operating procedures. For example, if they incur expenses in the same currency that their revenues are generated they will actually reduce their exchange rate risk exposure, naturally.

\section{Options $^{8}$}

A currency option (also known as a forex option) is a contract that gives the buyer the right, but not the obligation, to buy or sell a certain currency at a specified exchange rate on or before a specified date. For this right, a premium is paid to the seller.

\section{Speculation ${ }^{9}$}

In the world of finance, speculation, or speculative trading, refers to the act of conducting a financial transaction that has substantial risk of losing value but also holds the expectation of a significant gain or other major value. With speculation, the risk of loss is more than offset by the possibility of a substantial gain or other recompense.

\section{Transaction Exposure ${ }^{10}$}

Transaction exposure (or translation exposure) is the level of uncertainty businesses involved in international trade face. Specifically, it is the risk that currency exchange rates will fluctuate after a firm has already undertaken a financial obligation. A high level of vulnerability to shifting exchange rates can lead to major capital losses for these international businesses.

\section{Translation Exposure ${ }^{11}$}

Translation exposure (also known as translation risk) is the risk that a company's equities, assets, liabilities, or income will change in value as a result of exchange rate changes. This occurs when a firm denominates a portion of its equities, assets, liabilities, or income in a foreign currency. It is also known as "accounting exposure."

\footnotetext{
${ }^{8}$ https://www.investopedia.com/terms/c/currencyoption.asp\#: :text=a\%20Currency\%200ption,What\%20ls\%20a\%20Currency\%200ption\%3F,is\%20paid\%20to\%20the\%20seller.

${ }^{9}$ https://www.investopedia.com/terms/s/speculation.asp

${ }^{10}$ https://www.investopedia.com/terms/t/transactionexposure.asp\#: :text=Transaction\%20exposure\%20(or\% 20translation\%20exposure,already\%20undertaken\%20a\%20financial\%20obligation.

${ }^{11}$ https://www.investopedia.com/terms/t/translationexposure.asp\#: :text=Translation\%20exposure\%20(also\% 20 known\%20as,income\%20in\%20a\%20foreign\%20currency.
} 


\section{Biography of Arthur S. Guarino}

My professional career has been deeply involved in the financial services industry with such corporations as TIAA-CREF, Met Life, and The Bank of New York. I have held various positions in the financial services field including sales, training and development, administration, product development, customer service and relationship, and management. My teaching experience as a full-time instructor has been primarily at Stevens Institute of Technology in Hoboken, New Jersey and Rutgers University in Newark, New Jersey.

\section{Biography of Ronald Richter}

Professor Richter is Professor of Professional Practice in the Finance \& Economics at Rutgers Business School, and Principal Owner of his own Personal Financial Planning Practice. He has been associated with Rutgers University for over 25 years as both a student and professor. Prior to becoming a full-time Professor, Professor Richter worked in numerous corporate finance positions, working his way up to being a Chief Financial Officer at two companies, Subsequent to his corporate finance experience, Professor Richter started his own financial planning practice assisting his clients with investment, tax retirement and estate planning.

\section{Biography of Joshua Schupak}

Joshua Schupak is a senior at Rutgers Business School studying Business Analytics Information Technology as applied to the Financial Markets, Corporate Finance, and Sports Betting. He serves as the Technical Development Chair on the Business Information Technology Society. He is a former division one soccer player and served a term as president of the wrestling club. He is also an active chess and math competition coach. 